\title{
Quantifying supraglacial meltwater pathways in the Paakitsoq region, West Greenland
}

\author{
CONRAD KOZIOL, ${ }^{1}$ NEIL ARNOLD, ${ }^{1}$ ALLEN POPE, ${ }^{2,3,4}$ WILLIAM COLGAN ${ }^{3,5}$
}

\author{
${ }^{1}$ Scott Polar Research Institute, University of Cambridge, Lensfield Road, Cambridge, UK \\ ${ }^{2}$ National Snow and Ice Data Center, University of Colorado, Boulder, CO, USA \\ ${ }^{3}$ Cooperative Institute for Research in Environmental Sciences, Boulder, CO, USA \\ ${ }^{4}$ Polar Science Center, Applied Physics Lab, University of Washington, Seattle, WA, USA \\ ${ }^{5}$ Lassonde School of Engineering, York University, Toronto, Ontario, Canada \\ Correspondence: Conrad Koziol<cpk26@cam.ac.uk>
}

\begin{abstract}
Increased summer ice velocities on the Greenland ice sheet are driven by meltwater input to the subglacial environment. However, spatial patterns of surface input and partitioning of meltwater between different pathways to the base remain poorly understood. To further our understanding of surface drainage, we apply a supraglacial hydrology model to the Paakitsoq region, West Greenland for three contrasting melt seasons. During an average melt season, crevasses drain $\sim 47 \%$ of surface runoff, lake hydrofracture drains $\sim 3 \%$ during the hydrofracturing events themselves, while the subsequent surface-to-bed connections drain $\sim 21 \%$ and moulins outside of lake basins drain $\sim 15 \%$. Lake hydrofracture forms the primary drainage pathway at higher elevations (above $\sim 850 \mathrm{~m}$ ) while crevasses drain a significant proportion of meltwater at lower elevations. During the two higher intensity melt seasons, model results show an increase $(\sim 5$ and $\sim 6 \%$ of total surface runoff $)$ in the proportion of runoff drained above $\sim 1300 \mathrm{~m}$ relative to the melt season of average intensity. The potential for interannual changes in meltwater partitioning could have implications for how the dynamics of the ice sheet respond to ongoing changes in meltwater production.
\end{abstract}

KEYWORDS: crevasses, glacier hydrology, surface-melt

\section{INTRODUCTION}

The Greenland ice sheet (GrlS) has experienced elevated rates of melt since the 1990s (van den Broeke and others, 2009; Fettweis and others, 2011, 2013). In addition to driving surface mass loss, observations and modelling suggest that higher rates of surface melting may lead to dynamic changes of the ice sheet (Hewitt, 2013; Doyle and others, 2014; Moon and others, 2014; Tedstone and others, 2015; Van De Wal and others, 2015). Correlations between the summer melt season and increased summer ice velocities indicate that surface meltwater entering the subglacial system modulates water pressures, influencing ice velocities through changes in basal drag (Zwally and others, 2002; Bartholomew and others, 2011; Joughin and others, 2013; Fitzpatrick and others, 2013; Moon and others, 2014). Recent modelling studies of the subglacial hydrological system report that the temporal variability of meltwater input (Schoof, 2010; Hewitt, 2013) is an important control on basal drag. However, the role of the supraglacial hydrological system in determining spatial and temporal patterns of meltwater delivery to the ice-sheet bed remains poorly understood. Water draining into the englacial system can be trapped in crevasses, leading to modest increases in ice velocities due to cryohydrologic warming of the ice sheet (Van Der Veen and others, 2011; Phillips and others, 2013; Lüthi and others, 2015; Harrington and others, 2015; Poinar and others, 2016).

A significant proportion of surface meltwater drains via the subglacial system, with observations at the ice margin showing the majority of water exiting through subglacial channels and only limited flow over the ice edge (Zwally and others, 2002). Meltwater enters the subglacial system via crevasses, moulins and surface-to-bed connections created during lake hydrofracture events. Mapping of supraglacial stream networks in the ice-sheet watershed of Leverett glacier, southwest Greenland shows all meltwater rivers draining into the englacial hydrological system prior to reaching the ice margin (Smith and others, 2015). However, Poinar and others (2015) predict that surface stresses limit the formation of pathways from the surface to the ice bed to below 1600 m elevation; above this, observations show water draining over the ice-sheet surface many kilometers downstream to lower elevations before entering a meltwater pathway.

Surface meltwater on the GrlS forms stream networks and collects in lakes. Lakes may drain slowly by incision of a channel at their edge releasing water downstream, or drain rapidly through hydrofracture to the ice/bed interface (Tedesco and others, 2013). Hydrofracture events are hypothesized to be triggered when increased basal slip generates tensile stresses beneath lakes (Stevens and others, 2015). Since the observation that lake hydrofracture events temporarily increase local ice velocities (Das and others, 2008; Doyle and others, 2013; Tedesco and others, 2013), much work has been focused on understanding the relation between surface melt and lake distribution (Sundal and others, 2009; Selmes and others, 2011; Liang and others, 2012; Leeson and others, 2013; Morriss and others, 2013; Fitzpatrick and others, 2014).

Supraglacial modelling of the GrIS has focused on lake development and hydrofracture. Such models demonstrate that although lakes have limited storage capacity relative to 
annual surface melt (Leeson and others, 2012), hydrofracture events and the subsequent surface-to-bed connections created can transfer significant amounts of water to the bed (Banwell and others, 2012a; Arnold and others, 2014; Clason and others, 2015). To date, only Clason and others (2015) include surface drainage other than by lake hydrofracture, applying the method developed in Clason and others (2012) for the Devon Ice Cap. Drainage into crevasses and moulins outside of lake basins is simulated by applying a hydrofracture criterion, similar to that of lakes, to grid cells in the model where surface stresses exceed a prescribed surface tensile strength. Clason and others (2015) report that while surface-to-bed connections via lake hydrofracture have the dominant role above $\sim 1000$ m elevation, moulins and crevasses are the key transport mechanism below $\sim 1000 \mathrm{~m}$.

In this paper, we enhance the surface routing and lake filling (SRLF) component of the model of Banwell and others (2012a) and Arnold and others (2014) to allow drainage into crevasses and moulins outside of lake basins. Additionally, we also simulate the slow surface drainage of lakes via channel incision at their edge following Raymond and Nolan (2000), allowing water to escape from closed lake basins and potentially flow into downstream moulins, crevasses, or lakes. We apply the updated model to the Paakitsoq region of western Greenland over three melt seasons with contrasting melt intensities, incorporating moulins identified from high resolution satellite imagery, and crevassed areas determined from surface stresses derived from mean winter velocities. In order to better understand surface drainage, we use the model to quantify the partitioning of meltwater draining into moulins, crevasses and surface-to-bed connections from lake hydrofracture. We also investigate the spatial variability of surface drainage and the impact of higher intensity melt seasons.

\section{METHODS}

The SRLF model simulates surface flow and lake formation across the GrlS. It has been previously applied to a $\sim 100$ $\mathrm{km}^{2}$ area of the Paakitsoq region by Banwell and others (2012a) to successfully predict the filling of a supraglacial lake. When applied over a wider $\sim 3600 \mathrm{~km}^{2}$ area of the Paakitsoq region, SRLF model predictions using the Greenland Mapping Project (GIMP) DEM (Howat and others, 2015) show good agreement with observed lake depths and extents, as well as the generally observed spatiotemporal pattern of lake hydrofracture drainages (Arnold and others, 2014). Previous work with the model however, has neglected drainage into moulins outside of lake basins, as opposed to those caused by hydrofracture, and into crevasses. We develop the model in this paper to allow drainage into these surface features, as well as to allow lakes to drain through supraglacial channel incision.

The SRLF model requires a DEM of the study area, an ice thickness map and the locations of moulins and crevasses. The model is driven by time series of distributed melt runoff and distributed snow depth. We first discuss the formulation of the model itself before describing the study area, and the datasets used as model inputs and driving variables. We then discuss the design of the model runs used to explore the sensitivity of the model to certain parameters, and to assess the impact of different melt season intensities on the model results.

\subsection{Model formulation}

Water flow is modelled as Darcian flow in a saturated layer at the base of the snowpack when snow depth is $>0.7 \mathrm{~m}$, and as open channel flow otherwise. The $0.7 \mathrm{~m}$ snow depth threshold for stream formation is based on calibration simulations performed by Banwell and others (2012b). A single flow direction algorithm is used to determine water routing. For each sink cell in the model domain, the SRLF model calculates an input hydrograph by integrating the travel time of water in the cells forming the upstream catchment. Sink cells may be moulins, crevasses, lake depressions, or exit points on the lateral domain boundaries. All water entering moulins and crevassed cells is captured. We assume that these cells have either sufficient storage capacity or drain into the englacial system, and that overflow does not occur.

Depressions in the DEM collect water, forming lakes. Lake hydrofracture is modelled to occur when the volume of water in a lake is sufficient to fill a fracture penetrating the local ice thickness to the base. The length and width of the potential fracture are prescribed, using a fracture surface area parameter $\left(F_{\mathrm{a}}\right)$. The $F_{\mathrm{a}}$ parameter is constant across the whole model domain. Sensitivity analysis by Arnold and others (2014) show that a value of $F_{\mathrm{a}}$ in the range $4000-8000 \mathrm{~m}^{2}$ results in the best agreement between modelled and observed lake volumes from satellite imagery. If a lake induces hydrofracture, all additional water input into the lake depression is assumed to drain via a surface-to-bed connection located in the lowest cell of the depression, which remains open for the remainder of the melt season. Alternatively, a lake that is filled to capacity will route additional water into the downstream catchment; this can lead to incision of a channel at the lip, and can result in channelized supraglacial drainage.

Analysis of supraglacial lake drainage in Moderate-resolution Imaging Spectroradiometer (MODIS) imagery by Selmes and others (2013) shows that approximately a third of supraglacial lakes drain slowly over the surface of the ice. This is thought to occur through a channel incised at the edge of the lake into the ice by water draining from the lake (Selmes and others, 2013; Tedesco and others, 2013). Raymond and Nolan (2000) developed a spillway model (Fig. 1) to investigate lake drainage through such an exit channel, which we apply to lakes on the GrIS in the SRLF model. Our modelling implements Eqns (1) and (2), which describe the evolution of the channel and the lake surface height (Raymond and Nolan, 2000).

$$
\begin{aligned}
& \frac{\mathrm{d}}{\mathrm{d} t}\left(h_{\mathrm{s}}\right)=\frac{-\rho_{\mathrm{w}} g k \beta^{1 / 2}}{\rho_{i} L}(\beta+\gamma)\left(h_{\mathrm{l}}-h_{\mathrm{s}}\right)^{5 / 3} \\
& \frac{\mathrm{d}}{\mathrm{d} t}\left(h_{\mathrm{l}}\right)=\frac{-k \beta^{1 / 2} W_{\mathrm{s}}}{A_{\mathrm{l}}\left(h_{\mathrm{l}}\right)}\left(h_{\mathrm{l}}-h_{\mathrm{s}}\right)^{5 / 3}+\frac{Q_{i}}{A_{\mathrm{l}}\left(h_{\mathrm{l}}\right)}
\end{aligned}
$$

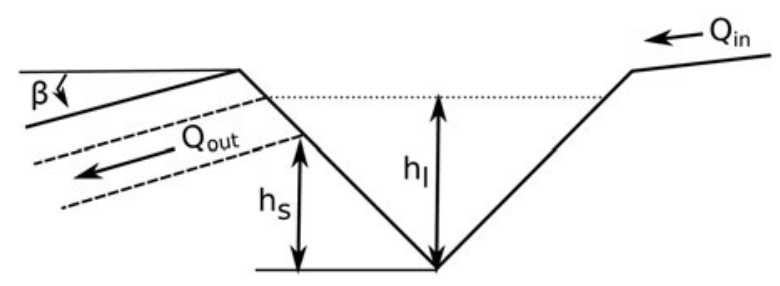

Fig. 1. Schematic cross section of a lake undergoing channelized drainage, which is modelled by Eqns (1) and (2), adapted from Raymond and Nolan (2000). 
where $h_{\mathrm{s}}$ is the height of the channel floor, $h_{i}$ is the height of the lake surface, $\rho_{\mathrm{w}}$ is the density of water, $\rho_{\mathrm{i}}$ is the density of ice, $g$ is the acceleration due to gravity, $k$ is a channel discharge parameter related to channel roughness and crosssection shape, $\beta$ is channel slope, $L$ is the latent heat of fusion per unit mass, $W_{\mathrm{s}}$ is channel width, $Q_{i}$ is water input into the lake and $A_{\mathrm{I}}$ is the surface area of the lake as a function of the height of the lake. The dimensionless heat transfer parameter $\gamma$ is defined as $\gamma=C_{w} T / g x$, where $C_{w}$ is the heat capacity per unit mass of water, $T$ is the temperature of water in a lake above the freezing point and $x$ is the distance over which the water temperature drops to the freezing point in a channel. A list of model parameters is given in Table 1.

The channel floor is melted due to heat dissipated from the water flowing in the channel. The model assumes two sources of heat. The first is the conversion of gravitational potential energy to heat, while the second is the thermal energy of the water exiting the lake. These are transferred to the channel floor according to the average slope of the channel and the rate of cooling of water in the channel. This is represented by the sum $(\beta+\gamma)$ in Eqn (1) (Raymond and Nolan, 2000).

Lakes form in depressions in the DEM, and are assumed to have an idealized conical hypsometry, the dimensions of which are derived from the topographic depression. Lakes overflow when the height of the water in the lake exceeds the lowest cell of the edge of the depression. Once a lake fills, we allow for two methods of drainage: overflow drainage and channelized drainage. Overflow drainage refers to when water beyond the capacity of the lake is removed and routed downstream from the lake outlet without contributing to channel incision. Channelized drainage refers to when a channel forms at the lake outlet, allowing water above the channel base to drain, with drainage deepening the channel; in this case, water drains from the lake, decreasing the volume of water.

In the SRLF model, all lakes which do not hydrofracture have the potential to drain over the ice-sheet surface. Channelized drainage is assumed to occur only if the channel elevation decreases faster than the lake water height (i.e. $\left.\mathrm{d} / \mathrm{d} t\left(h_{\mathrm{s}}\right)<\mathrm{d} / \mathrm{d} t\left(h_{\mid}\right)\right)$. Otherwise, only simple

Table 1. Table of parameters and values for SRLF model simulations

\begin{tabular}{|c|c|c|c|}
\hline Description & Symbol & Value & Units \\
\hline Acceleration due to gravity & $g$ & 9.8 & $\mathrm{~ms}^{-2}$ \\
\hline Density of water & $\rho_{w}$ & 1000 & $\mathrm{kgm}^{-3}$ \\
\hline Density of ice & $\rho_{i}$ & 916 & $\mathrm{kgm}^{-3}$ \\
\hline Channel discharge parameter & $k$ & 10 & $\mathrm{~m}^{1 / 3} \mathrm{~s}^{-1}$ \\
\hline Latent heat of fusion & $L$ & $3.35 \times 10^{5}$ & $\mathrm{Jg}^{-1}$ \\
\hline Fracture area threshold & $F_{\mathrm{a}}$ & & $\mathrm{m}^{2}$ \\
\hline Initial channel depth & $C_{i}$ & & $\mathrm{~m}$ \\
\hline Yield strength & $\sigma_{y}$ & & $\mathrm{kPa}$ \\
\hline Heat transfer parameter & $\gamma$ & & \\
\hline Lake elevation & $h_{1}$ & & $\mathrm{~m}$ \\
\hline Channel elevation & $h_{\mathrm{c}}$ & & $\mathrm{m}$ \\
\hline Surface area of lake & $A_{1}$ & & $\mathrm{~m}^{2}$ \\
\hline Water input to lake & $Q_{\text {in }}$ & & $\mathrm{m}^{3} \mathrm{~s}^{-1}$ \\
\hline Water output from lake & $Q_{\text {out }}$ & & $\mathrm{m}^{3} \mathrm{~s}^{-1}$ \\
\hline Channel slope & $\beta$ & & \\
\hline Channel width & $W_{\mathrm{s}}$ & 5 & $\mathrm{~m}$ \\
\hline
\end{tabular}

The first section lists physical constants, the second section lists model parameters. overflow drainage is assumed to occur. Channelized and overflow drainage occur simultaneously if water drainage through a channel is not sufficient to prevent the lake surface height from rising above the limit of the topographic depression.

The model requires a fixed initial channel geometry. The initial depth is set as a model parameter, while the width is set to a fixed value of $5 \mathrm{~m}$, which was selected as a representative value of the range of channel widths observed in WorldView imagery. The top of the channel is set at the elevation of the lake edge. Fixed channel dimensions are necessary since channel initiation is not modelled, and since channels in the model only incise downwards, not outwards. We use the same initial geometry for all channels in the model domain. Channels are assumed to open instantaneously once drainage begins, simulating rapid removal of blocking snow. This assumption implies that any channelization from previous years will only have an effect up to the initial channel depth, neglecting the impact of previous years melt intensity on channel formation. Once a channel opens, the channel begins to incise following Eqns (1) and (2). Since channel drainage depends on $Q_{i}$, the method of drainage for lakes undergoing overflow drainage is re-evaluated each time step. Alternatively, if channelized drainage does not occur, excess water is removed via overflow drainage.

The change in lake height and channel bottom height are modelled using the ode15s solver in Matlab. If the lake is draining via a channel, and there is an input of water greater than the channel can discharge, causing the water volume in the lake to exceed the volume of the DEM depression, excess water is removed via simple overflow. There is no mechanism for channels to close, and all water entering a fully drained lake is routed downstream.

Following Arnold and others (2014) we initiate each model run with a DEM devoid of water. This assumption is based on statistics from Johansson and others (2013), who reported that for a study area south of the Paakitsoq region $78-88 \%$ of lakes below $2500 \mathrm{~m}$ drained during the 200709 melt seasons. Similar to Arnold and others (2014), we impose no-inflow boundary conditions, while allowing water to flow out of the model domain. This is justified on the eastern boundary as it extends beyond $1500 \mathrm{~m}$, where melt is limited. The northern and southern boundaries of the model were selected to be approximately perpendicular to elevation contours leading to limited outflow; modelling results (see Section 3 ) show that $\sim 11 \%$ of surface melt generated in the study area exits through the northern and southern boundaries. Outflow from the western boundary represents water flowing off the ice sheet.

\subsection{Study area and DEM}

We apply the SRLF model to a land terminating sector of the GrlS in the Paakitsoq region of western Greenland (Fig. 2). The study area is $\sim 31 \mathrm{~km}$ in width, $\sim 84 \mathrm{~km}$ in length and $\sim 2368 \mathrm{~km}^{2}$ in area. The GIMP DEM at $90 \mathrm{~m}$ resolution is used as input to the SRLF model for all three melt seasons. Following Arnold and others (2014), we smooth the DEM using a $2 \times 2$ cell median filter to remove small scale noise, and then an $11 \times 11$ cell Guassian filter to remove the 'terracing' effect of the $1 \mathrm{~m}$ vertical resolution of the data.

Previous work (Arnold and others, 2014) found good agreement between the GIMP DEM and observed lake 


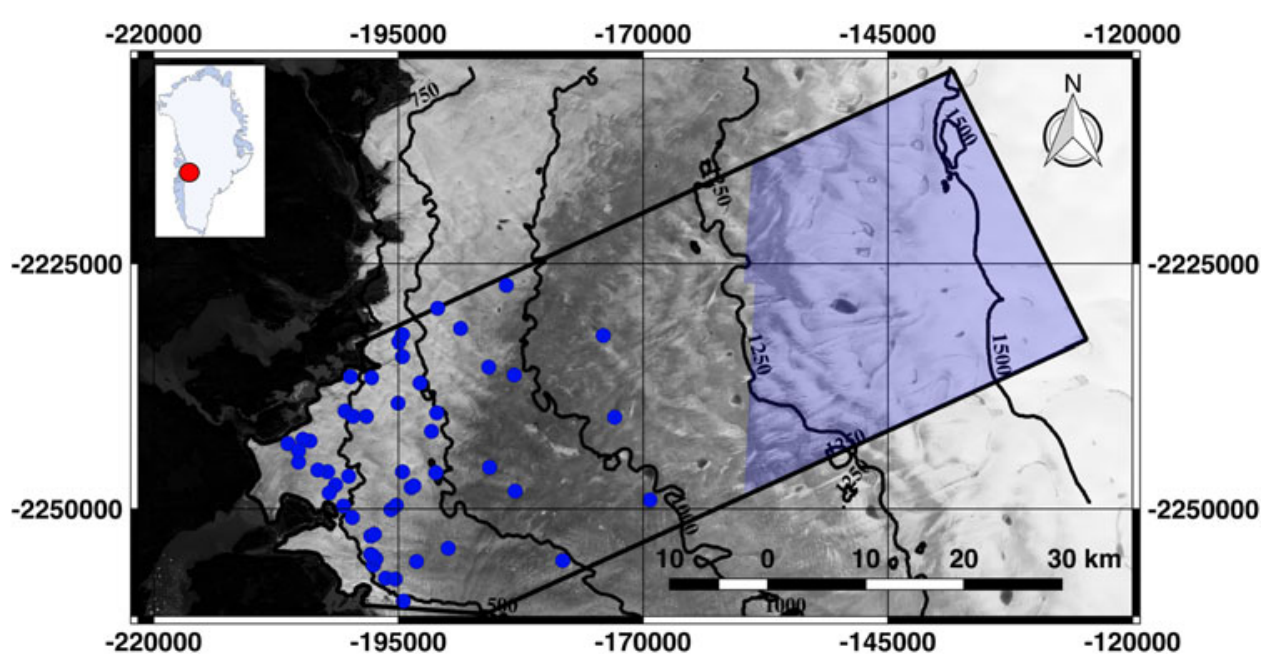

Fig. 2. Location map of the study area. Black outline shows the model domain, while blue markings denote moulin locations derived from WorldView imagery. Blue highlight indicates where appropriate WorldView imagery was unavailable. Base-map shows a Landsat-8 image from 4 August 2014; contour lines are from the GIMP DEM (Howat and others, 2015). Red dot in inset locates the Paakitsoq region in Greenland.

locations and volumes in Landsat imagery. Since lake forming depressions are controlled by basal topography, and are not observed to advect with ice flow (Echelmeyer and others, 1991; Selmes and others, 2011), we expect the locations of lake depressions in the DEM to be valid over multiple melt seasons.

Yang and others (2015) report that calculated stream networks from DEMs match the broad scale drainage patterns mapped from satellite imagery. Comparison of stream locations (Fig. 3) mapped for 2009 to those in 1985 (Thomsen, 1988) over a portion of the Paakitsog region shows that streams develop over a similar area. We therefore also expect stream locations derived from the DEM to be applicable over multiple melt seasons.

Lake hydrofracturing can be conceptualized as dependent on the ice thickness and threshold water volume (Krawczynski and others, 2009). To determine ice thicknesses, we employ the BedMachine dataset (Morlighem and others, 2014, 2015).

\subsection{Crevasse and moulin locations}

We use the von Mises yield criterion (Vaughan, 1993; Clason and others, 2015) to predict the occurrence of crevassed

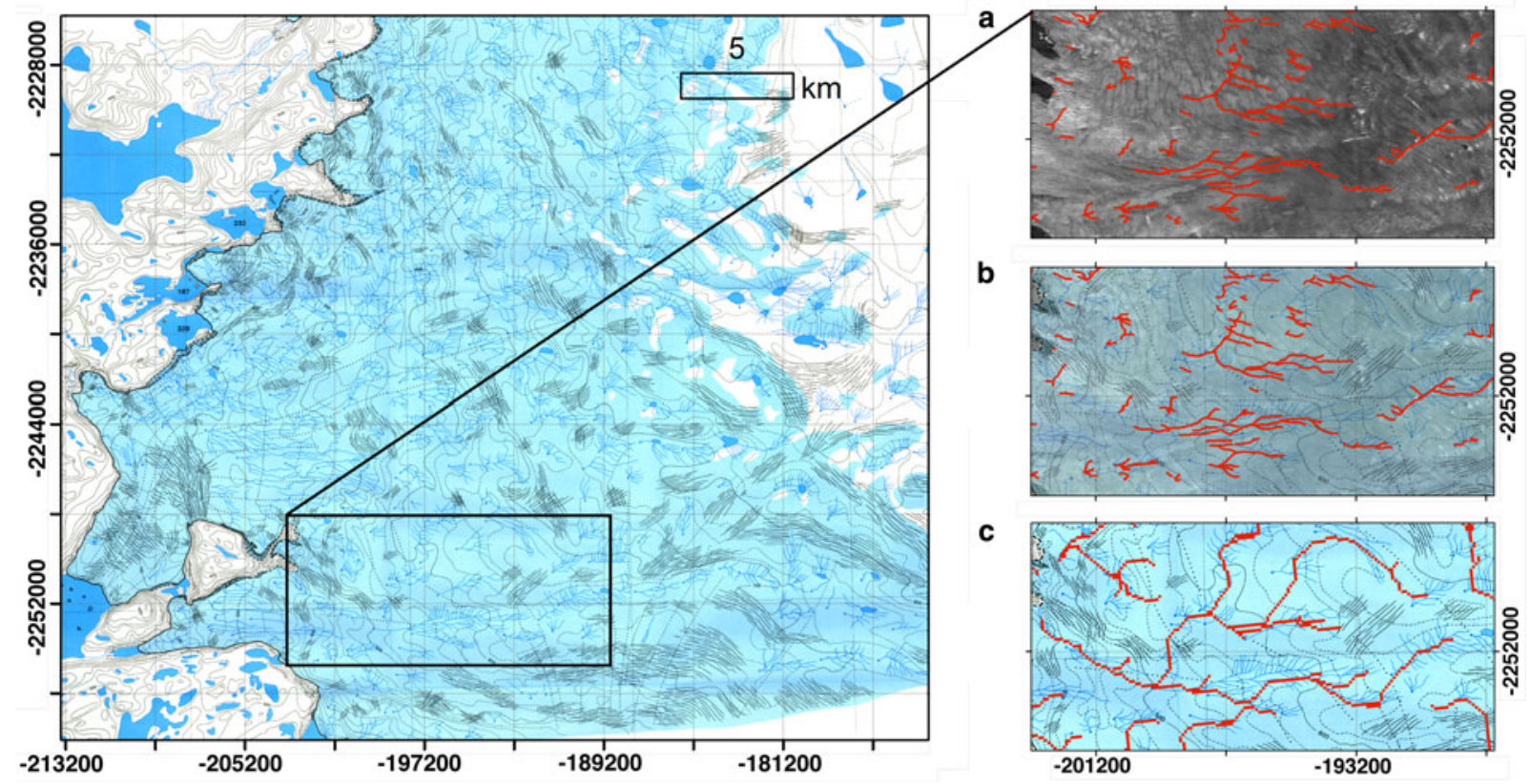

Fig. 3. Supraglacial hydrological features delineated within the Paakitsoq region. Main panel: Map of Paakitsoq region showing surface features, including stream locations (Thomsen, 1988). Inset: (a) Supraglacial stream positions delineated in 2009 WorldView imagery (red markings) overlain on the WorldView image. (b) Supraglacial stream positions delineated in 2009 WorldView imagery (red markings) overlain on the map by Thomsen (1988) highlighting coincidence of stream locations. (c) Calculated supraglacial stream locations overlain on the map by Thomsen (1988). 
areas in the study site (Fig. 4). Surface stresses derived from winter velocities (Joughin and others, 2010a, b) are used to determine von Mises stresses across the study area. Following Clason and others (2015), we visually compare the distribution of von Mises stress to areas of crevassing observed in satellite imagery to determine a yield strength $\left(\sigma_{y}\right)$. Crevasses are predicted to form in cells where the von Mises stress exceeds the yield strength. A yield strength of $132.5 \mathrm{kPa}$ is determined to have the best visual match between predicted crevasses and the prominent crevasse fields in the lower study area. We perform a sensitivity test using yield strengths of 125 and $140 \mathrm{kPa}$, which increase and decrease the crevassed area by 32 and $25 \%$, respectively.

WorldView images acquired during the 2009 and 2010 melt seasons were visually inspected to determine moulin locations. Although these images provide good coverage of the lower and mid elevations of our study area, suitable WorldView imagery is unavailable for the uppermost region of the study site (Fig. 2). However, since we observe moulin density to decrease away from the ice margin in the available imagery, we do not expect moulins to occur outside of lake basins in the upper region of the study site.

Moulins are identified in the imagery as the abrupt ending of a stream. In total 45 moulins are identified, which are located outside of topographic depressions in the DEM.
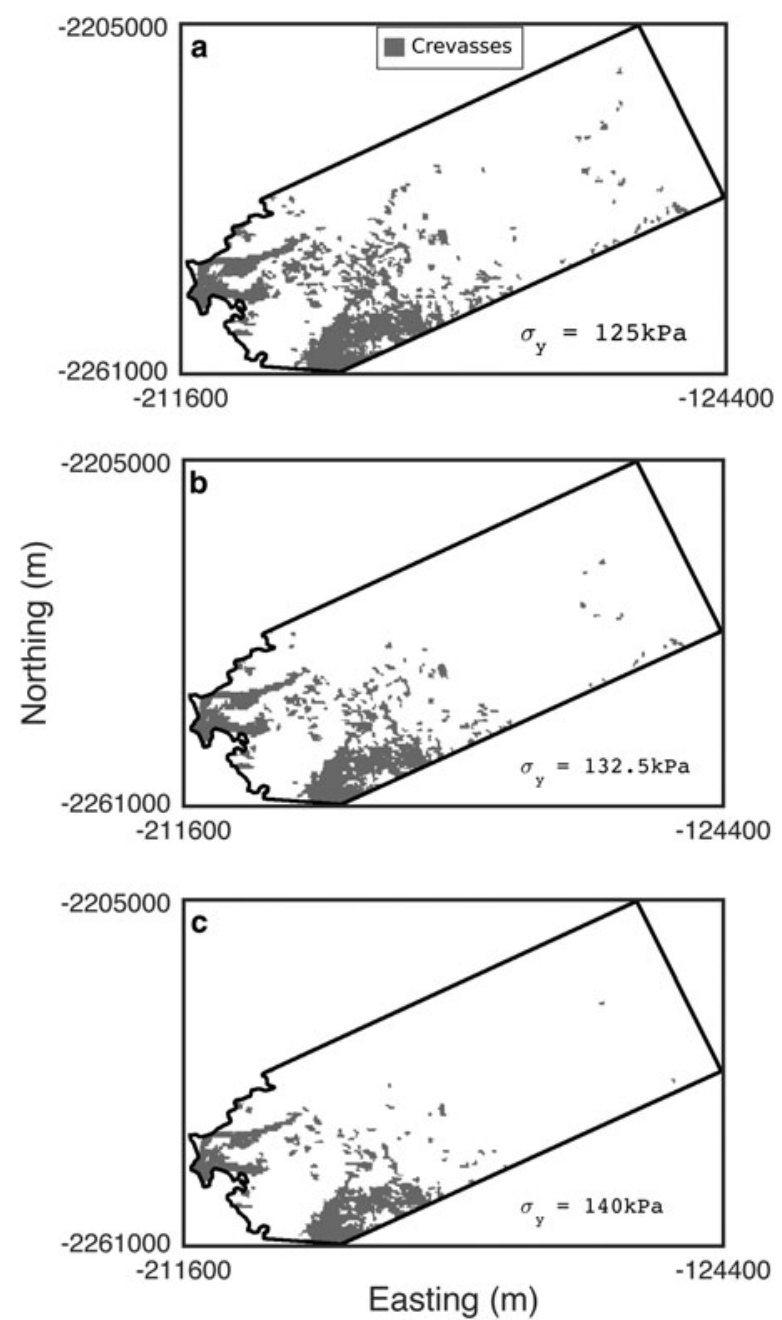

Fig. 4. Predicted crevassed areas in the study domain for three different ice yield strengths. (a) $125 \mathrm{kPa}$. (b) $132.5 \mathrm{kPa}$. (c) $140 \mathrm{kPa}$.
The SRLF model is initialized with moulins at these locations. Moulins with locations coincident with depressions in the DEM are not used; rather, we allow the SRLF model to predict whether a surface-to-bed connection will form by lake hydrofracture in these locations. The locations of the 45 moulins outside of DEM depressions are compared with the drainage paths calculated for the DEM with an upstream area calculation using a single flow direction algorithm. Similarly to Yang and others (2015), we find that simulated supraglacial stream channel positions deviate slightly from those observed in imagery. We therefore adjust the position of these 45 observed moulin positions to align with simulated stream channels. Any moulins not falling on a simulated stream location are relocated to the nearest DEM cell with a simulated stream. The mean distance these 45 moulins are moved is $198 \mathrm{~m}$, which is approximately two DEM grid cells. For moulins on potential stream paths that were calculated to be $>1$ cell wide $(90 \mathrm{~m})$, the effective moulin radius was set so that the moulin would capture all water in the stream, rather than allowing some water to effectively bypass the adjacent moulin.

\subsection{Driving variables}

Daily melt runoff and snow depth input data for the SRLF model is provided by RACMO2.3 regional climate model simulations (Noël and others, 2015). Melt runoff is defined as the total volume of melt in a cell minus the volume of melt which refreezes. The years 2009, 2011 and 2012 are selected on the basis of their contrasting melt intensities (Fig. 5). Study area wide melt volumes for the 3 years selected are $3.46 \times 10^{9} \mathrm{~m}^{3}, 4.24 \times 10^{9} \mathrm{~m}^{3}$ and $5.39 \times 10^{9} \mathrm{~m}^{3}$, respectively. These three melt years are used as analogues for average, elevated and extreme melt years. RACMO2.3 model output was provided on a daily temporal resolution, at $11 \mathrm{~km}$ spatial resolution. The data are bilinearily interpolated to $90 \mathrm{~m}$ resolution. Snow depth is updated daily in the SRLF model. To simulate an idealized diurnal melt cycle, melt runoff is interpolated to hourly time steps using a normal distribution with peak melt between 14:00 and 15:00 (in line with McGrath and others (2011)), with a standard deviation of $2 \mathrm{~h}$. Melt outside a $9 \mathrm{~h}$ window centred on

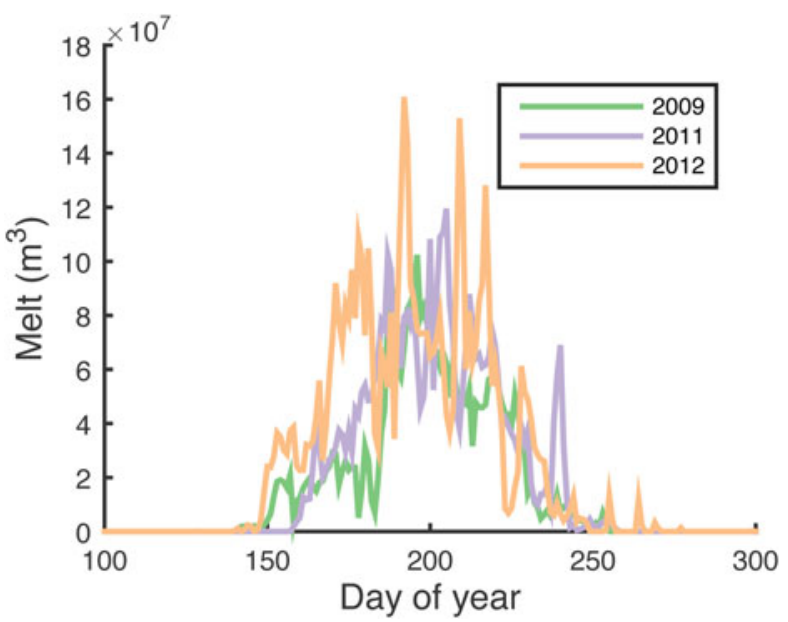

Fig. 5. Time series of daily melt in the study area for the 2009, 2011 and 2012 melt seasons modelled by RACMO2.3 (Noël and others, 2015). We use these 3 years as analogues for average, elevated and extreme melt years, respectively. 
peak melt is set to zero. The area within the $9 \mathrm{~h}$ window is normalized such that the total volume of daily melt is unaltered. We run the SRLF model for the summer melt season, which we define as day 135 of the year (15 May) to day 274 of the year (1 October), based on daily melt volume (Fig. 5).

\subsection{Simulation design}

We calibrate the SRLF model using lake drainage statistics for southwest Greenland during the 2009 melt season (Table 2) and perform 11 model simulations (Table 3). Lake drainage statistics were provided by Nick Selmes (personal communication, 31 October 2014), derived from data presented in Selmes and others (2013). R1 is the standard calibrated model run for 2009, and gives the best match to lake drainage statistics. We perform sensitivity analyses on channelization parameters (runs R2-R5), the fracture area parameter (runs R6-R7) and crevasse extent (runs R8-R9) to understand the impact of the updated model components. The standard model is then run with different climate input (runs R10-R11) to investigate the impact of contrasting melt season intensity on supraglacial drainage. Parameter values for runs R1-R11 are shown in Table 3. There is the potential for 225 lakes with an area greater than the minimum MODIS pixel size $\left(0.0625 \mathrm{~km}^{2}\right)$ to form within the study area. In model run R1, all of these lakes are filled sufficiently to cover one MODIS pixel. Our analysis focuses on these lakes, as the lake statistics we employ to calibrate our model result from an analysis of MODIS imagery (Selmes and others, 2013). This is in line with the results of Yang and others (2015), who report that errors in DEM lead to an overprediction of small lakes when compared with satellite imagery. The area threshold $0.0625 \mathrm{~km}^{2}$ we employ, however, is smaller than the range of values $0.1-0.2 \mathrm{~km}^{2}$ suggested from their preliminary analysis.

\section{RESULTS}

\subsection{Standard run}

Simulation results show the majority of water in the study area drains into the englacial hydrological system (Fig. 6). Of the total surface melt, $15 \%$ drains into moulins outside of lake basins, while surface-to-bed connections from the 24 lakes which hydrofractured capture $24.3 \%$. We divide the volume entering the englacial system through hydrofracturing into two components, the water that is in a lake when hydrofracture occurs, and subsequent drainage into the moulin that results from hydrofracture. We refer to the former as 'Lake Hydrofracture Lake' ('LHL'), and the latter as 'Lake Hydrofracture Moulin' ('LHM'). Only 3.3\% of total surface melt drains via $\mathrm{LHL}$, while $21 \%$ of total surface

Table 2. Remotely sensed and modelled lake drainage statistics for 2009

\begin{tabular}{lcclc}
\hline & $\begin{array}{l}\text { Hydrofracture } \\
\text { drainage }(\%)\end{array}$ & $\begin{array}{l}\text { Channelized } \\
\text { drainage }(\%)\end{array}$ & $\begin{array}{l}\text { None } \\
(\%)\end{array}$ & $\begin{array}{l}\text { Unknown } \\
(\%)\end{array}$ \\
\hline Observed & 11.7 & 38.9 & 43.8 & 5.6 \\
Modelled (R1) & 10.7 & 37.8 & 51.5 & 0
\end{tabular}

Remote sensing statistics are for the whole of southwest Greenland, while model output is limited to the study site (Selmes and others, 2013).
Table 3. Values of parameters that are varied between each of the model runs. Bold text highlights values that change between rows

\begin{tabular}{llllll}
\hline Model run & $C_{i}$ & $Y$ & $F_{\mathrm{a}}$ & $\sigma_{\mathrm{y}}$ & Melt intensity \\
\hline R1 & 0.15 & 0.075 & 4000 & 132.5 & Average \\
R2 & $\mathbf{0 . 0 1}$ & 0.075 & 4000 & 132.5 & Average \\
R3 & $\mathbf{0 . 3}$ & 0.075 & 4000 & 132.5 & Average \\
R4 & 0.15 & $\mathbf{0 . 0 5}$ & 4000 & 132.5 & Average \\
R5 & 0.15 & $\mathbf{0 . 1}$ & 4000 & 132.5 & Average \\
R6 & 0.15 & 0.075 & $\mathbf{2 0 0 0}$ & 132.5 & Average \\
R7 & 0.15 & 0.075 & $\mathbf{6 0 0 0}$ & 132.5 & Average \\
R8 & 0.15 & 0.075 & 4000 & $\mathbf{1 2 5}$ & Average \\
R9 & 0.15 & 0.075 & 4000 & $\mathbf{1 4 0}$ & Average \\
R10 & 0.15 & 0.075 & 4000 & 132.5 & Elevated \\
R11 & 0.15 & 0.075 & 4000 & 132.5 & Extreme \\
& & & & & \\
\hline
\end{tabular}

Model run R1 is the calibrated model run, R2-R5 are sensitivity tests to channelized drainage parameters, R6-R7 are sensitivity tests of hydrofracturing, R8-R9 are sensitivity tests to crevasse extent, and R10-R11 are sensitivity tests of melt season intensity.

melt drains via LHM. Crevasses in run R1 drain $46.6 \%$ of surface melt. Only a small proportion of water drains over the ice edge or remains on the surface of the ice sheet, with $3 \%$ flowing over the ice margin and $0.6 \%$ remaining in lakes at the end of the model run. $9.2 \%$ of surface melt leaves the model domain across the northern and southern edges.

The volume of surface drainage decreases away from the ice-sheet margin, with the exception of the $0-8.4 \mathrm{~km}$ band (Fig. 7). Surface drainage is greatest in the $8.4-16.8 \mathrm{~km}$ band, where $20.25 \%$ of the total surface runoff generated in our study area drains. Crevasses drain water throughout the study area. Within $42 \mathrm{~km}$ of the ice-sheet margin, crevasses are responsible for over $54 \%$ of the surface drainage in each distance band. Water drained by moulins is concentrated between 8.4 and $25.2 \mathrm{~km}$ from the study site margin. Approximately $83 \%$ of the water entering into moulins does so within this area. Lake hydrofracture and subsequent surface-to-bed connections drain water upstream of $16.8 \mathrm{~km}$. Except for the interval between 33.6 and $42 \mathrm{~km}$, lake hydrofracture captures over $34 \%$ of meltwater in each distance band above $25.2 \mathrm{~km}$.

Figure 8 shows the location and extent of lake basins within the study area, and whether the lakes which formed within them drained via channelized drainage, hydrofracture, or remained at the end of the melt season. We assume any lakes remaining at the end of the melt season freeze. The majority of lake hydrofracture events occurred inland of $25 \mathrm{~km}$ from the ice margin, with only one out of 24 hydrofracture events occurring closer to the ice-sheet margin. The low surface drainage via lake hydrofracture between 33.6 and $42 \mathrm{~km}$ corresponds to an area where only two hydrofracture events occur. The model predicts that channelized drainage and lake freezing can occur throughout the study site.

Model calibration results in 85 out of 225 lakes draining over the ice sheet through a channel at their edge. Two representative hydrographs of lakes that completely drained over the ice sheet via channelization are shown in Figure 9. In the early stages of channelized drainage, channel depth increases while lake elevation and volume remain close to, or at, the level of maximum lake capacity. Because the lake is at capacity, any water input must be balanced by the equivalent outflow. 


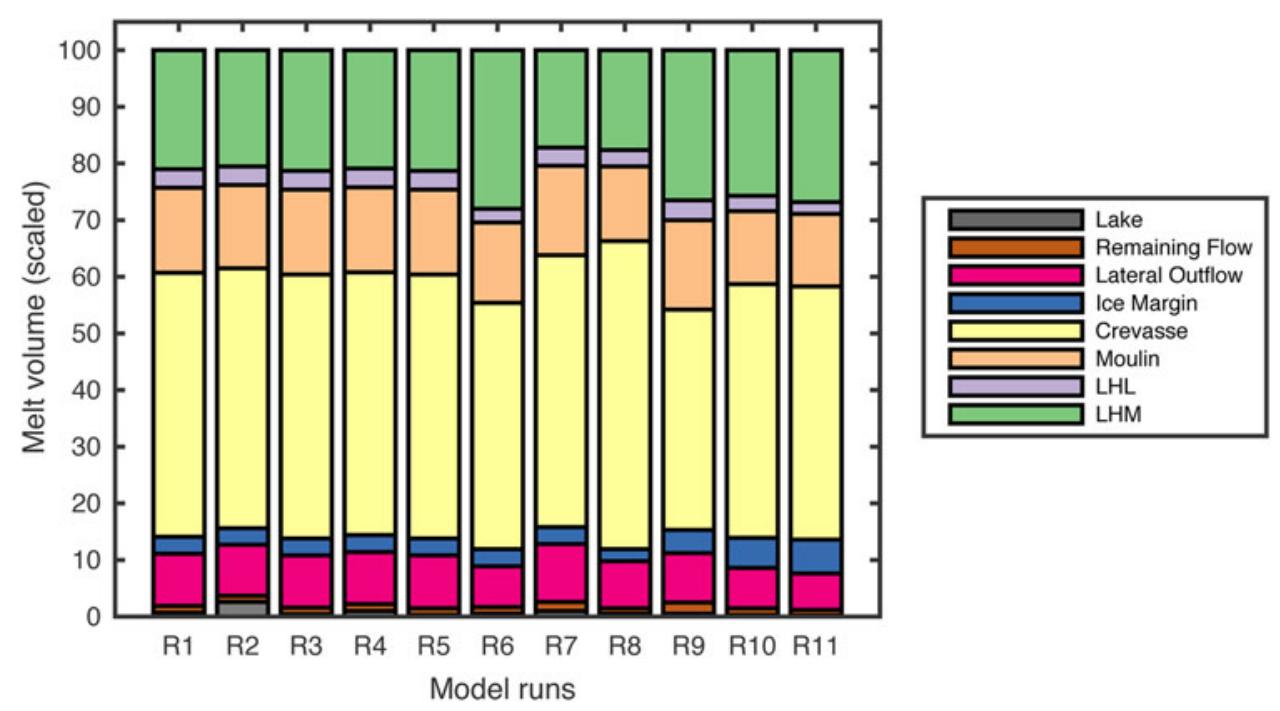

Fig. 6. Partitioning of surface melt for the standard run (R1), model sensitivity analysis (R2-R9), and for different melt season intensities (R10R11). Water stored in category 'Lake' is defined as the volume that remains in lakes at the end of the melt season. 'Remaining Flow' is the amount of water that is still in transit at the end of the simulation. 'Lateral Outflow' is defined as the volume of water that exits our model through the northern and southern boundaries. Water flow on the ice-sheet edge is partitioned into the 'Ice Margin' category. The volumes of water captured in crevasses and moulins are partitioned into 'Crevasse' and 'Moulin', respectively. We divide the volume of water drained by surface-to-bed connections resulting from lake hydrofracture into two categories: 'lake hydrofracture lake' (LHL) and 'lake hydrofracture moulin' (LHM). The initial volume of water in a lake when hydrofracture occurs is partitioned into 'LHL', while subsequent drainage into the surface-to-bed connection is partitioned into 'LHM'.

Figure 9a/b shows an unstable channelized lake drainage where the rate of channel incision accelerates throughout the lake drainage. Channel incision continues when the channel elevation drops below the bottom of the lake, and the final channel elevation can be metres below the lake bottom elevation. The observable lake drainage event, from the time the lake is last full to complete drainage, occurs on the timescale of days. During this period, the output hydrograph shows a
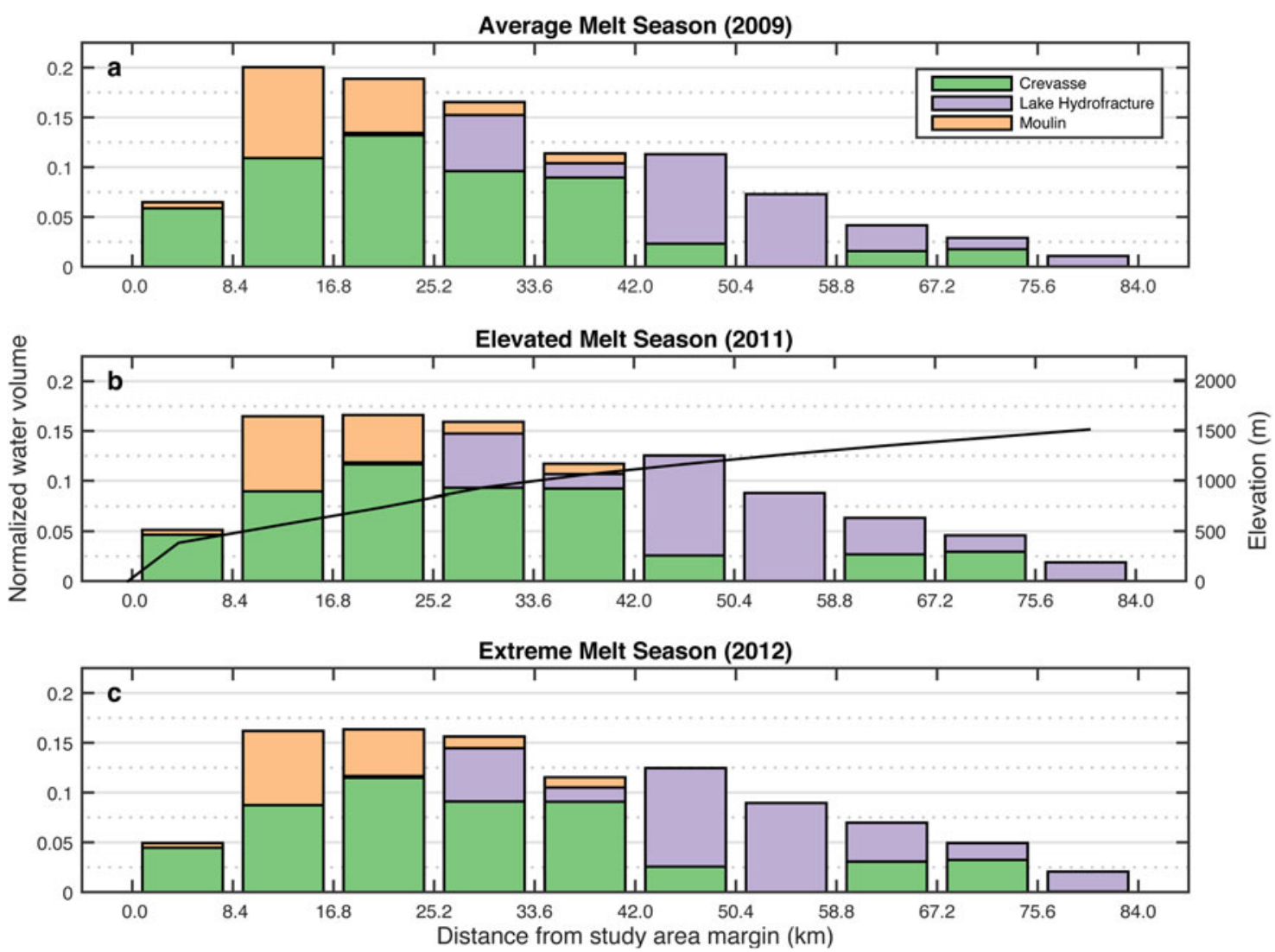

Fig. 7. Bar chart showing partitioning of water into different pathways at different distance bands from the study site margin. The three charts correspond to each of the melt season intensities tested: (a) average melt year (2011), (b) elevated melt year (2011), (c) extreme melt year (2012). Black line in middle plot shows width-averaged elevation profile of the study area. 


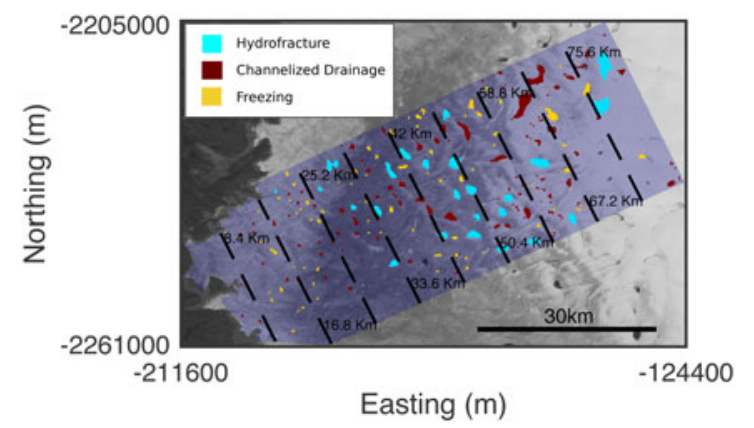

Fig. 8. Lake depressions with areas $>0.0625 \mathrm{~km}^{2}$. The colour of the lake depression corresponds to the fate of the lake that formed in the depression during model simulation R1. Lake hydrofracture and channelized drainage processes are modelled, while lakes which remain at the end of the melt season are assumed to freeze. Blue highlight shows the model study area, with distance bands overlain.

rapid increase in lake output to a sharp peak, followed by a steep decline. Peak lake discharge is $36.4 \mathrm{~m}^{3} \mathrm{~s}^{-1}$. Diurnal variations in water output are masked during the observable lake drainage event.

Figure $9 \mathrm{c} / \mathrm{d}$ shows a representative lake drainage event where the rate of channel incision decelerates during the observable lake drainage event, increasing the period over which the lake drains. Although the observable lake drainage event takes place over many weeks, the bulk of the lake drains over a period of 1-2 weeks. The output hydrograph is broader than in the unstable lake drainage, and the lake output flux does not exceed the maximum diurnal input flux. Diurnal cycles in lake output are dampened but remain visible. As the lake approaches being completely drained, lake output progressively mirrors water input.

\subsection{Sensitivity analysis}

\subsubsection{Channelization parameters (R2-R5)}

We test the sensitivity of our model to two channel drainage parameters, the initial depth of the channel that forms $\left(C_{i}\right)$, and the heat transfer parameter $(\gamma)$. The influence of these parameters on lake drainage is shown in Table 4. The number of lakes with channelized drainage was not sensitive to these parameters; however, the number of lakes which completely drain varies considerably with the channel drainage parameters. Although changes to the lake drainage parameters have a large proportional impact on the storage capacity of the system, the absolute change in the partitioning of surface melt is relatively small (Fig. 6). At the end of run $\mathrm{R} 10.6 \%$ of the total surface melt is stored in lakes. In our sensitivity analysis of lake drainage parameters, the percentage of surface melt stored in lakes at the end of
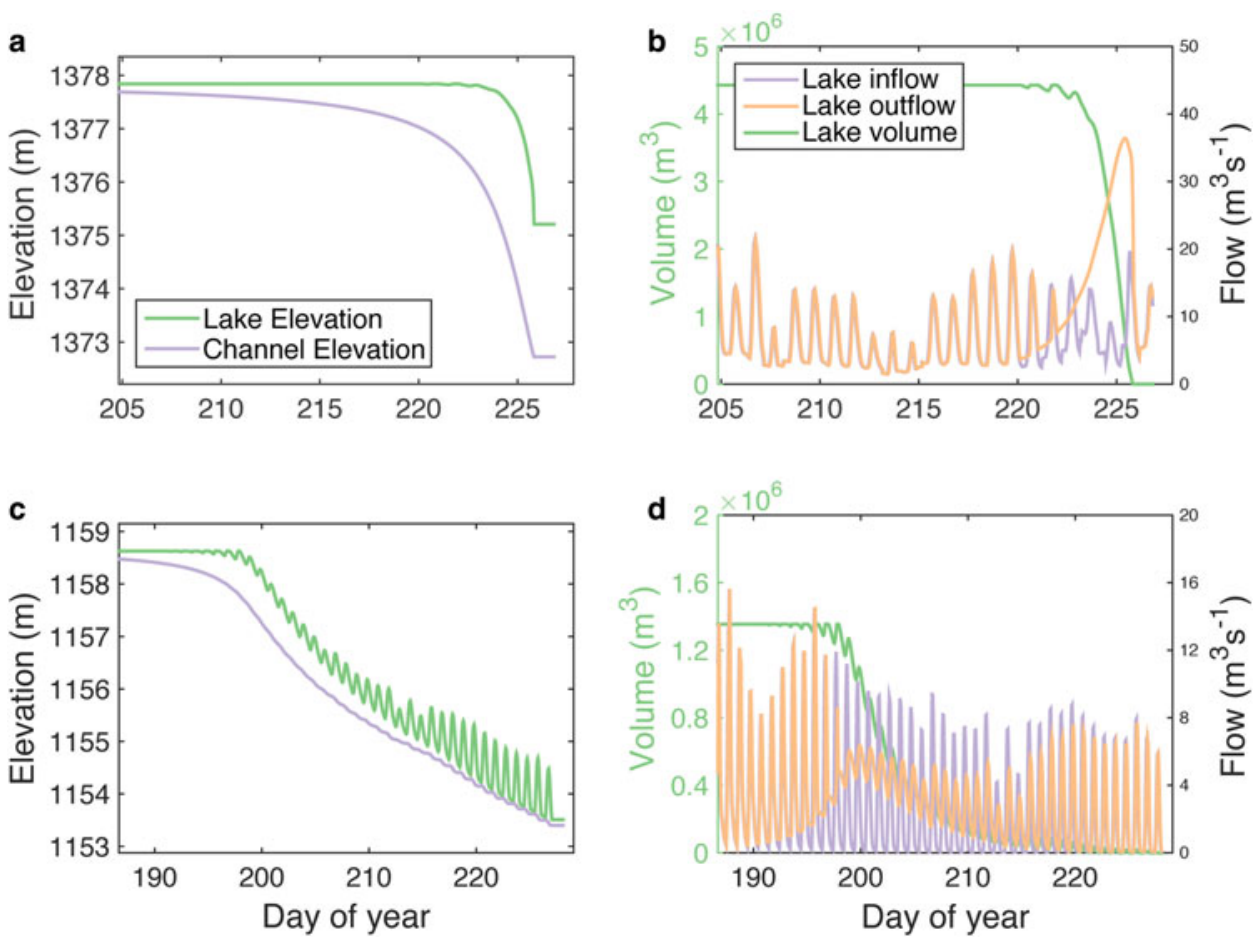

Fig. 9. Plots detailing channelized drainage of two different lakes which are representative of lakes which drain unstably (a/b), and of lakes which have initially unstable drainage but which do not continue draining unstably (c/d). Plots a and c show the lake and channel elevations, while plots $b$ and $d$ show the lake volume, lake input and lake output.

Table 4. Statistics of lake hydrofracture and lake drainage via channelization for each of the modelled runs

\begin{tabular}{|c|c|c|c|c|c|c|c|c|c|c|c|}
\hline & R1 & R2 & R3 & R4 & R5 & R6 & R7 & R8 & R9 & R10 & R11 \\
\hline Lakes hydrofractured & 24 & 24 & 24 & 24 & 24 & 35 & 16 & 20 & 27 & 24 & 24 \\
\hline Lakes with channelized drainage & 190 & 190 & 186 & 190 & 190 & 176 & 199 & 182 & 196 & 190 & 190 \\
\hline Lakes drained completely via channelization & 85 & 1 & 110 & 47 & 115 & 79 & 86 & 83 & 98 & 98 & 124 \\
\hline
\end{tabular}


simulations increases to a maximum of $2.5 \%$ in run $\mathrm{R} 2$, and decreases to a minimum of $0.3 \%$ in $\mathrm{R} 4$.

\subsubsection{Fracture area (R6-R7)}

The fracture area parameter $\left(F_{\mathrm{a}}\right)$ determines the volume at which a lake hydrofractures. Simulation R1 is run with a parameter value of $4000 \mathrm{~m}^{2}$ (within the range of best fit of Arnold and others (2014)), and predicts 24 lakes hydrofracturing. The number of lakes which hydrofacture is sensitive to $F_{\mathrm{a}}$, increasing to 35 in R6 and decreasing to 16 in R7. This has a negligible impact on surface storage in lakes $(\leqslant 0.4 \%$ of total surface runoff), but changes the total proportion of surface melt drained by lake hydrofracture and the subsequent surface-to-bed connection from $24.3 \%$ in R1, to $30.4 \%$ in R6 and $20.4 \%$ in R7.

\subsubsection{Crevasse extent (R8-R9)}

To quantify the uncertainty associated with the extent of crevassed areas, we perform two model simulations (R8-R9) with crevasse extent determined by different ice yield strengths. Simulation R1 is run with a yield stress of 132.5 $\mathrm{kPa}$, which we perturb by $\pm 7.5 \mathrm{kPa}$ in simulations $\mathrm{R} 8$ and R9. A yield strength of $125 \mathrm{kPa}$ (R8) increases the crevassed area extent by $32 \%$, and the proportion of water entering crevasses from 46.6 to $54.4 \%$. Similarly, increasing the yield strength to $140 \mathrm{kPa}$ (R9) decreased the crevasse extent by $25 \%$, and decreases proportion of water entering crevassed areas to $38.9 \%$ of total surface runoff.

\subsection{Interannual comparison (R10-R11)}

Model simulations R10 and R11 correspond to the 2011 (elevated) and 2012 (extreme) melt seasons. In both simulations, the number of lakes which hydrofractured was the same as in simulation R1. However, the proportion and volume of water drained by lake hydrofracture and the subsequent surface-tobed connection increases from $24.3 \%\left(0.84 \mathrm{~km}^{3}\right)$ in $\mathrm{R} 1$ to $28.4 \%\left(1.20 \mathrm{~km}^{3}\right)$ in $\mathrm{R} 10$ and $28.9 \%\left(1.55 \mathrm{~km}^{3}\right)$ in $\mathrm{R} 11$. Because lake drainages are triggered by a volumetric threshold, the volume of water draining via LHL remained constant at $0.11 \mathrm{~km}^{3}$ in all the three melt seasons. This results in the proportion of total melt draining via $\mathrm{LHL}$ decreasing from $3.3 \%$ in $\mathrm{R} 1$ to $2.7 \%$ in $\mathrm{R} 10$, and $2.1 \%$ in $\mathrm{R} 11$. Increases in the proportion of water drained by lake hydrofracture therefore come from increased drainage in LHM. Between R1 and R10, drainage via LHM increased from $21 \%\left(0.73 \mathrm{~km}^{3}\right)$ to $25.7 \%\left(1.09 \mathrm{~km}^{3}\right)$. Between R10 and R11 there is a smaller increase of $1.1 \%$, from 25.7 to $26.8 \%\left(1.44 \mathrm{~km}^{3}\right)$ in drainage via LHM. While the proportion of water drained by lake hydrofracture increases, the proportion drained by crevasses and moulins outside of lake basins decreases. In R1, moulins capture $15 \%$ of melt, while in R10 and R11, moulins capture 12.9 and $12.8 \%$ of surface runoff, respectively.

Although the proportion of total surface meltwater draining via moulins decreases, the volume of surface melt draining via moulins increases from $0.52 \mathrm{~km}^{3}$ in $\mathrm{R} 1$, to $0.55 \mathrm{~km}^{3}$ and $0.69 \mathrm{~km}^{3}$ in R10 and R11. Similarly, crevasses capture $46.6 \%$ of surface runoff in R1, but only $44.8 \%$ of surface runoff in R10. In R11, this proportion remains approximately the same at $44.7 \%$. However, the volume of surface melt draining via crevasses increases from 1.61 to $1.90 \mathrm{~km}^{3}$ and $2.41 \mathrm{~km}^{3}$ as melt intensity increases.
As melt intensity increases from average to elevated, a higher proportion of meltwater is predicted to drain further from the ice margin (Fig. 7). Compared with simulation R1, each distance band up to $33.6 \mathrm{~km}$ from the study margin in simulation R10 drains a smaller proportion of water, while each distance band above $33.6 \mathrm{~km}$ drains an increased proportion of water. Changes in each distance band are limited to a few percent of total surface runoff. The maximum decrease was in distance band $8.4-16.8 \mathrm{~km}$, which drained $3.5 \%$ less of total surface runoff, while the maximum increase was in distance band 58.8-67.2 km, which drained $2.3 \%$ more total surface runoff.

Although the proportion of total melt runoff drained by the distance band $8.4-16.8 \mathrm{~km}$ decreased, the volume of water drained in this band remained approximately the same at $0.60 \mathrm{~km}^{3}$. In the distance band $58.8-67.2 \mathrm{~km}$, the volume of water drained increased from 0.12 to $0.23 \mathrm{~km}^{3}$. While there is a marked upslope shift in surface drainage between R1 and R10, between R10 and R11 there is only a small change in the spatial distribution of water drainage.

The cumulative proportion of surface runoff drained above $58.8 \mathrm{~km}(\sim 1300 \mathrm{~m})$ in our study area is $7.16 \%$ in $\mathrm{R} 1,11.18 \%$ in $\mathrm{R} 10$ and $12.21 \%$ in $\mathrm{R} 11$.

Although the number of lakes with channelized drainage does not increase in simulations R10 and R11, the number of lakes which completely drain over the ice sheet through channelization increases from 85 to 98 in R10, and up to 124 in R11 (Table 4).

\section{DISCUSSION}

A key overall prediction from our modelling results is that only $3-6 \%$ of surface melt flows off the edge of the ice sheet, and under $1 \%$ remains in storage in lakes on the surface of the ice sheet. Over $\sim 85 \%$ percent of water is modelled to drain into the ice sheet, with $\sim 9 \%$ percent leaving through the lateral study area margins. Assuming the water leaving through the lateral margins remains in lakes and drains off the ice margin in a similar proportion, then over $95 \%$ of water drains into the englacial system.

This is in clear agreement with the results of Smith and others (2015), who report that surface storage during 2012 in their study area was limited compared with the amount of melt generated, and that all observed surface rivers drained into the ice sheet. This is also consistent with other studies of the Paakitsoq region, which suggest that water draining into deep crevasses contributes to cryohydrological warming of the ice sheet (Phillips and others, 2013; Lüthi and others, 2015). Of the different meltwater pathways, drainage into crevassed areas is the most significant route for water to enter the ice sheet ( $47 \%$ of overall melt). Drainage via the moulins established by lake hydrofracture accounts for $\sim 24 \%$ (but the hydrofracture events themselves only account for $\sim 3 \%$ ), and other moulins account for $\sim 15 \%$.

Similarly to Yang and others (2015) we find agreement between observed moulins and predicted supraglacial stream locations. We also similarly find broad scale agreement between calculated stream networks and those observed in recent WorldView imagery. A comparison of stream networks observed in 1985 and 2009 reveals similar network structure, suggesting that the broad-scale pattern of stream networks remains similar over decadal timescales. Previous work (Arnold and others, 2014) has found good agreement between lakes predicted from the GIMP DEM 
and observed locations/depths. Since surface storage on the ice-sheet surface is low, false positive filling of lakes should have a negligible impact. This suggests that current high resolution DEMs, in conjunction with moulins and crevasse locations derived from remote sensing, provide a suitable dataset for surface hydrology models.

The partitioning of drainage is spatially variable over the study area. Similarly to Clason and others (2015), and consistent with Joughin and others (2013), we find that drainage via lake hydrofracture is a significant drainage pathway at higher elevations (above $\sim 850 \mathrm{~m}$ ). Moulins are shown to primarily drain water near the ice-sheet margin. Crevasses drain water throughout the study area, although drainage into crevasses is concentrated at lower elevations where their extent is greatest. The spatial distribution of different meltwater pathways may have an important role in modulating the variability of surface runoff to the bed, as crevasses are predicted to dampen diurnal meltwater fluctuations reaching the ice/ bed interface relative to moulins (McGrath and others, 2011). Thus, within the Paakitsoq region, we would expect changes in runoff variability to be more effectively transmitted to the ice/bed interface at higher elevations, where crevasses drain a smaller proportion of surface runoff. Given that subglacial hydrological models suggest that it is the variability of water inputs, rather than the total amount of input that is the key control on basal drag (Schoof, 2010; Hewitt, 2013) this could imply that the seasonal variability of icesheet velocity could be larger at higher elevations on the ice sheet.

While channelized lake drainage has minimal impact on meltwater partitioning in our model due to the limited capacity of lakes relative to total surface runoff, channelized lake drainage changes the timing and characteristics of water flow downstream of lakes. As observed by Tedesco and others (2013), channelized drainage events which flow into a downstream moulin can temporarily increase ice velocities. Our study reproduces the observed timescale of days to several weeks for lakes draining over the ice sheet via channelization (Selmes and others, 2013; Tedesco and others, 2013). In our model, rapid drainage of lakes on the timescale of days occurs if channel incision is unstable such that the decrease in the elevation of the bed of the channel is faster than the lowering of the lake surface. Our model also shows a different mode of channelized drainage, on the timescale of weeks, in which drainage switches from unstable to stable drainage in which the rate of channel incision matches the lowering of the lake surface. The diversity of behaviour agrees with Kingslake and others (2015), who find that the stability of channelized drainage is controlled by lake geometry, channel slope and melt input.

The sensitivity analysis can be divided into simulations testing model parameters (R2-R7) and simulations testing model inputs (R8-R11). We find that while the number of lakes which undergo channelized drainage is insensitive to channelization parameter values, the number of lakes which drain completely is strongly controlled by the initial depth of the channel that forms (R2-R3) and the heat transfer parameter (R4-R5). The sensitivity to the initial depth parameter suggests that features below our DEM resolution, particularly relic channelization from previous years and small scale topography around the rim of the lake (which we do not directly allow for, but which the initial channel depth simulates to some degree) could have a significant role in determining whether channelized drainage occurs, and the timescale over which lakes drain. Because of the sensitivity to the heat transfer parameter, possible spatial and temporal variation in lake temperature (due to different meteorological conditions) could also impact the pattern and timing of lake drainages.

Our results (R8-R9) show that while varying yield strength can make a large difference in the overall area predicted to be crevassed $(\sim 30 \%)$, the impact on the overall partitioning of meltwater is more muted ( $\sim 8 \%$ of total surface runoff). While Colgan and others (2011) show an increase in the crevassed area of 13\% between 1985 and 2009 (using satellite imagery), our results suggest that such a change would have a relatively minor impact on melt partitioning. However, if this rate of expansion continues, long term changes in crevasse distribution may become important for melt partitioning.

Melt availability (R10-R11) affects two aspects of model behaviour. Higher meltwater production causes hydrofracture events to occur earlier in the melt season (as lakes will reach the critical volume for fracture more quickly). This has no impact on the volume of water drained during the event itself, but could lead to an earlier development of an efficient subglacial drainage system, resulting in an earlier summer slowdown (Bartholomew and others, 2010; Schoof, 2010; Sundal and others, 2011; Cowton and others, 2013). Higher melt availability also increases the number of modelled lakes that drain completely by channelized drainage. This reduces the total amount of water stored on the ice sheet at the end of the summer (though as stated, this is a very small proportion of the overall melt). Warmer melt seasons may also increase the temperature of water in lakes, increasing the amount of energy available for channels to incise into the ice-sheet surface (simulated at present using the heat transfer parameter, $\gamma$ ).

The spatial distribution of surface drainage shows some sensitivity to melt availability. As melt season intensity rises from average to elevated, the proportion of water drained beyond $58.8 \mathrm{~km}(\sim 1300 \mathrm{~m})$ from the ice-sheet margin increases by $\sim 5 \%$ of total surface runoff. Drainage via surface-to-bed connections created by lake hydrofracture forms an increased proportion of meltwater, while crevasses and moulins outside of lake basins drain a decreased proportion of meltwater. However, the partitioning of water between elevated and extreme melt seasons remains similar, with only a small increase $(\sim 1 \%$ of total surface runoff) in the proportion of water drained at higher elevations. This shows melt partitioning does not consistently vary interannually, nor linearly with melt season intensity.

There are some aspects of the observed behaviour of the supraglacial drainage system which our model cannot capture. The observed interannual variability of the behaviour of lakes suggests that a subset of the lake population is capable of both hydrofracture and channelized drainage (Selmes and others, 2013), with the mechanism of drainage determined by an unknown preconditioning. This competition is not directly captured in our model largely due to the limitations of the fracture area criterion, which effectively pre-determines lakes that can drain via hydrofracture; such lakes can never incise a channel at their lip, as hydrofracture will prevent them filling to the maximum volume determined by the ice-sheet topography, a pre-condition in our model for channelized drainage. Lakes for which the topographically controlled maximum volume is smaller than the threshold volume for hydrofracture can never exhibit hydrofracture, 
but can only overflow. However, here the model does allow for some year-on-year variability, as the channelization mechanism does depend on the rate of incision of the channel versus the rate at which the lake surface elevation changes. Thus, in any given year, a lake could show simple overflow drainage, or stable or unstable channelized drainage, depending on the rate of water inputs to the lake versus water outflow. We cannot however simulate the possible existence of a deeply incised channel from a previous year, which could prevent a lake from forming at all in extreme cases, as has effectively been inferred by Smith and others (2015), who observed that in certain cases, streams on the ice sheet had effectively cut through local topographic divides.

Ultimately, it seems very unlikely that a model could ever predict the possible behaviour over several years of any individual lake. At a catchment or regional scale, however, it may be that some form of stochastic variations in the fracture area threshold (potentially linked to a local strain threshold) could allow the statistical properties of a set of lakes to be simulated more effectively than in a deterministic model. Such a model, applied in a form of Monte-Carlo analysis, might allow the range of possible water inputs to a subglacial hydrological model to be simulated more effectively for a range of melt scenarios, in turn allowing more effective simulation of the possible impact of climate change on ice dynamics.

\section{CONCLUSIONS}

In this paper we have applied a model of supraglacial hydrology to the Paakitsoq region of western Greenland for 3 years: 2009, 2011 and 2012. The model is forced using melt rates and snow depths from a regional climate model (Noël and others, 2015), simulates water flow over a DEM of the surface of the ice sheet (Howat and others, 2015), and allows surface water to accumulate as lakes in topographically controlled basins. Water can enter the englacial hydrological system via water-volume-driven lake hydrofracture events, through observed moulins, and via crevassed areas, determined from surface stresses derived from mean winter velocities. Lakes can also drain supraglacially via simple topographic overflow, and via the incision of supraglacial streams into the lips damming lakes.

The model has been used to better understand the partitioning of water routes into the en- (and potentially, therefore, the sub-) glacial drainage system. Previous modelling studies have typically focused on hydrofracture beneath supraglacial lakes (Banwell and others, 2012a; Arnold and others, 2014; Clason and others, 2015), although Clason and others (2015) also allow for hydrofracture to occur outside lake basins. Observational studies have shown that drainage outside of lake basins can deliver significant volumes of water to the englacial system (Smith and others, 2015; Yang and others, 2015), so the incorporation of drainage into crevasses or moulins at locations derived from remote sensing data (rather than solely at locations depending on hydrofracture) allows our model to more realistically reflect these observations.

Our results produce a suite of behaviours that agree well with observations of lake behaviour. Modelled lakes can drain via hydrofracture, they can drain slowly (over days to weeks) via the incision of supraglacial channels, and some lakes simply remain full at the end of the melt season, and are assumed to freeze over winter. Overall, over 95\% of available melt in the model likely enters the englacial drainage system. In our standard run (with parameter values chosen to match observed frequencies of lake behaviour), crevassed areas drain $47 \%$ of the available melt, $24 \%$ drains through the surface-to-bed connections established by lake hydrofracture events and $15 \%$ via moulins located outside of lake basins. In the case of hydrofracture events, the bulk of this water actually enters the glacier after the fracture event itself, via streams flowing into the fracture established during the event; a very small proportion (3\%) is drained during the events themselves. This reflects the small overall volume of supraglacial lakes compared with the total volume of melt produced in a typical melt season. These proportions are affected to some extent by the parameter values chosen, but the overall balance of partitioning of melt is robust, as is the finding that almost all water enters the ice sheet. Channelized surface drainage of lakes does not alter the overall partitioning of meltwater routing into the ice sheet, but has been observed to impact the timing of lake hydrofracture downstream (Banwell and others, 2012a; Tedesco and others, 2013).

The model results show limited sensitivity to melt intensity; in the warmer years (2011 and 2012) the proportion of water which drains via hydrofracture increases at the expense of the other two routes, driven largely by the earlier occurrence of hydrofracture events as lakes reach the critical volume for hydrofracture earlier in the melt season.

The partitioning of melt drainage varies spatially over the ice sheet, with moulin drainage more common at lower elevations and hydrofracture more important at higher elevations. Drainage via crevasses occurs at all elevations, but is concentrated at lower elevations where they are more common. Higher melt intensity leads to a change in this spatial partitioning, with an increase in hydrofracture events at higher elevations at the expense of the other two routes.

Our results have important implications in terms of the potential impact of supraglacially-derived water on icesheet dynamics. In terms of the overall partitioning of meltwater, we find that crevasses capture a significant proportion of supraglacial meltwater. This implies that the possible mechanisms which could link water in surface crevasses to the subglacial drainage system are important to understand. We also find that the total volume of water transported to the bed via lake hydrofracture events in themselves is small in comparison with the total amount of water entering the system subsequently via the newly created moulins. While lake drainage events, and the very high discharges associated with them, seem likely to remain a key control on the development of subglacial drainage networks (e.g. Das and others, 2008; Doyle and others, 2014), as melt increases, and lake drainage events potentially occur earlier in the melt season, the subsequent drainage (and the characteristics of such flow) could become increasingly significant in terms of icesheet dynamics and potential summer velocity change. This also relates to our finding that the partitioning of meltwater can change with melt season intensity, but does not do so in a straightforward or linear manner. While interannual variations in melt intensity could affect ice dynamics, this would depend on the nature of the supraglacial drainage system and its sensitivity to melt availability, and also on the sensitivity of the subglacial system itself to changes in the partitioning of water inputs. 
The model developments we have implemented here allow a more diverse and realistic set of behaviours for supraglacial water than has been possible in previous studies. They have allowed us to estimate the proportions of water entering the ice sheet via different drainage paths, and how this balance varies spatially. This study has also allowed us to begin to estimate how changes in melt intensity could affect the balance in the routes by which meltwater enters the ice sheet, which could have implications for how the dynamics of the ice sheet may change in response to ongoing climatic changes. In future developments, we are working to link the model described here to a coupled subglacial hydrology/ice dynamics model in order to begin to quantify these changes.

\section{ACKNOWLEDGMENTS}

We acknowledge M.R. van den Broeke and B. Noël for providing RACMO2.3 data. We thank Nick Selmes for providing data pertaining to lake drainage statistics. C.P. Koziol acknowledges the support of St. John's College (Cambridge). A. Pope was supported by NSF award GEO1331100 and W. Colgan was supported by NASA award NNX13AP73G. WorldView imagery was provided by the Polar Geospatial Center at the University of Minnesota, which is supported by grant ANT-1043681 from the US National Science Foundation. We also thank Neil Glasser and two anonymous reviewers whose comments greatly improved this paper.

\section{REFERENCES}

Arnold NS, Banwell AF and Willis IC (2014) High-resolution modelling of the seasonal evolution of surface water storage on the Greenland ice sheet. Cryosphere, 7(8), 1149-1160 (doi: 10.5194/tc-8-1149-2014)

Banwell AF, Arnold NS, Willis IC, Tedesco M and Ahlstrøm AP (2012a) Modeling supraglacial water routing and lake filling on the Greenland Ice Sheet. J. Geophys. Res., 117(F4), F04012, ISSN 0148-0227 (doi: 10.1029/2012JF002393)

Banwell AF and 6 others (2012b) Calibration and evaluation of a high-resolution surface mass-balance model for Paakitsoq West Greenland. J. Glaciol., 58(212), 1047-1062, ISSN 00221430 (doi: 10.3189/2012JoG12J034)

Bartholomew I and 5 others (2010) Seasonal evolution of subglacial drainage and acceleration in a Greenland outlet glacier. Nat. Geosci., 3(6), 408-411, ISSN 1752-0894 (doi: 10.1038/ngeo863)

Bartholomew I and 6 others (2011) Seasonal variations in Greenland Ice Sheet motion: inland extent and behaviour at higher elevations. Earth Planet. Sci. Lett., 307(3-4), 271-278, ISSN 0012821X (doi: 10.1016/j.epsl.2011.04.014)

Clason C, Mair DW, Burgess DO and Nienow PW (2012) Modelling the delivery of supraglacial meltwater to the ice/bed interface: application to southwest Devon Ice Cap, Nunavut, Canada. J. Glaciol., 58(208), 361-374, ISSN 00221430 (doi: 10.3189/ 2012JoG11J129)

Clason CC and 6 others (2015) Modelling the transfer of supraglacial meltwater to the bed of leverett glacier, southwest Greenland. Cryosphere, 9(1), 123-138 (doi: 10.5194/tc-9-123-2015)

Colgan W and 7 others (2011) An increase in crevasse extent, West Greenland: Hydrologic implications. Geophys. Res. Lett., 38(18) (doi: 10.1029/2011GL048491)

Cowton T and 7 others (2013) Evolution of drainage system morphology at a land-terminating Greenlandic outlet glacier. J. Geophys. Res.: Earth Surf., 118(1), 29-41, ISSN 21699003 (doi: 10.1029/2012JF002540)
Das SB and 6 others (2008) Fracture propagation to the base of the Greenland Ice Sheet during supraglacial lake drainage. Science (New York, N.Y.), 320(5877), 778-781, ISSN 1095-9203 (doi: 10.1126/science.1153360)

Doyle SH and 9 others (2013) Ice tectonic deformation during the rapid in situ drainage of a supraglacial lake on the Greenland Ice Sheet. Cryosphere, 7(1), 129-140, ISSN 1994-0424 (doi: 10.5194/tc-7-129-2013)

Doyle SH and 6 others (2014) Persistent flow acceleration within the interior of the Greenland ice sheet. Geophys. Res. Lett., 41(3), 899-905, ISSN 1944-8007 (doi: 10.1002/2013GL058933), 2013GL058933

Echelmeyer K, Clarke T and Harrison W (1991) Surficial glaciology of Jakobshavns Isbræ, West Greenland: Part I. Surface morphology. J. Glaciol., 37(127), 368-382

Fettweis X, Tedesco M, van den Broeke M and Ettema J (2011) Melting trends over the Greenland ice sheet (1958-2009) from spaceborne microwave data and regional climate models. Cryosphere, 5(2), 359-375, ISSN 1994-0424 (doi: 10.5194/tc5-359-2011)

Fettweis X and 5 others (2013) Brief communication: important role of the mid-tropospheric atmospheric circulation in the recent surface melt increase over the Greenland ice sheet. Cryosphere, 7(1), 241-248, ISSN 1994-0424 (doi: 10.5194/tc7-241-2013)

Fitzpatrick AAAW and 8 others (2013) Ice flow dynamics and surface meltwater flux at a land-terminating sector of the Greenland ice sheet. J. Glaciol., 59(216), 687-696, ISSN 00221430 (doi: 10.3189/2013JoG12J143)

Fitzpatrick AAW and 9 others (2014) A decade (2002€-2012) of supraglacial lake volume estimates across Russell Glacier, West Greenland. Cryosphere, 8(1), 107-121, ISSN 1994-0424 (doi: 10.5194/tc-8-107-2014)

Harrington JA, Humphrey NF and Harper JT (2015) Temperature distribution and thermal anomalies along a flowline of the Greenland Ice Sheet. Ann. Glaciol., 56(70), 98-104, ISSN 02603055 (doi: 10.3189/2015AoG70A945)

Hewitt I (2013) Seasonal changes in ice sheet motion due to melt water lubrication. Earth Planet. Sci. Lett., 371-372, 16-25, ISSN 0012821X (doi: 10.1016/j.epsl.2013.04.022)

Howat I, Negrete A and Smith B (2015) Measures Greenland Ice Mapping Project (gimp) Digital Elevation Model, version 1. 90 $m$ Resolution. NASA National Snow and Ice Data Center Distributed Active Archive Center, Boulder, Colorado, USA (doi: 10.5067/NV34YUIXLP9W)

Johansson A, Jansson P and Brown I (2013) Spatial and temporal variations in lakes on the Greenland Ice Sheet. J. Hydrol., 476, 314320, ISSN 00221694 (doi: 10.1016/j.jhydrol.2012.10.045)

Joughin I, Smith BE, Howat IM, Scambos T and Moon T (2010a) Greenland flow variability from ice-sheet-wide velocity mapping. J. Glaciol., 56(197), 415-430, ISSN 00221430 (doi: 10.3189/002214310792447734)

Joughin I, Smith BE, Howat IM, Scambos T and Moon T (2010b) MEaSUREs Greenland Ice Velocity Map from InSAR Data. NASA DAAC at the National Snow and Ice Data Center, Boulder, Colorado, USA (doi: 10.5067/MEASURES/ CRYOSPHERE/nsidc-0478.001)

Joughin I and 9 others (2013) Influence of ice-sheet geometry and supraglacial lakes on seasonal ice-flow variability. Cryosphere, 7(4), 1185-1192, ISSN 1994-0424 (doi: 10.5194/tc-7-11852013)

Kingslake J, Ng F and Sole A (2015) Modelling channelized surface drainage of supraglacial lakes. J. Glaciol., 61(225), 185-199, ISSN 00221430 (doi: 10.3189/2015JoG14J158)

Krawczynski MJ, Behn MD, Das SB and Joughin I (2009) Constraints on the lake volume required for hydro-fracture through ice sheets. Geophys. Res. Lett., 36(10), L10501, ISSN 0094-8276 (doi: 10.1029/2008GL036765)

Leeson AA, Shepherd A, Palmer S, Sundal A and Fettweis X (2012) Simulating the growth of supraglacial lakes at the western 
margin of the Greenland ice sheet. Cryosphere, 6(5), 1077-1086, ISSN 1994-0424 (doi: 10.5194/tc-6-1077-2012)

Leeson AA and 7 others (2013) A comparison of supraglacial lake observations derived from MODIS imagery at the western margin of the Greenland ice sheet. J. Glaciol., 59(218), 11791188, ISSN 00221430 (doi: 10.3189/2013JoG13J064)

Liang YL and 7 others (2012) A decadal investigation of supraglacial lakes in West Greenland using a fully automatic detection and tracking algorithm. Remote Sens. Environ., 123, 127-138, ISSN 00344257 (doi: 10.1016/j.rse.2012.03.020)

Lüthi MP and 7 others (2015) Heat sources within the Greenland Ice Sheet: dissipation, temperate paleo-firn and cryo-hydrologic warming. Cryosphere, 9(1), 245-253, ISSN 1994-0424 (doi: 10.5194/tc-9-245-2015)

McGrath D, Colgan W, Steffen K, Lauffenburger P and Balog J (2011) Assessing the summer water budget of a moulin basin in the Sermeq Avannarleq ablation region, Greenland ice sheet. J. Glaciol., 57(205), 954-964 (doi: 10.3189/00221431 1798043735)

Moon T and 6 others (2014) Distinct patterns of seasonal Greenland glacier velocity. Geophys. Res. Lett., 41(20), 7209-7216, ISSN 1944-8007 (doi: 10.1002/2014GL061836)

Morlighem M, Rignot E, Mouginot J, Seroussi H and Larour E (2014) Deeply incised submarine glacial valleys beneath the Greenland ice sheet. Nat. Geosci., 7(6), 418-422, ISSN 1752-0894 (doi: 10.1038/ngeo2167)

Morlighem M, Rignot E, Mouginot J, Seroussi H and Larour E (2015) IceBridge BedMachine Greenland, Version 1, Thickness. NASA DAAC at the National Snow and Ice Data Center, Boulder, Colorado, USA (doi: 10.5067/AD7B0HQNSJ29)

Morriss BF and 7 others (2013) A ten-year record of supraglacial lake evolution and rapid drainage in West Greenland using an automated processing algorithm for multispectral imagery. Cryosphere, 7(6), 1869-1877, ISSN 1994-0424 (doi: 10.5194/ tc-7-1869-2013)

Noël B and 5 others (2015) Summer snowfall on the Greenland ice sheet: a study with the updated regional climate model racmo2.3. Cryos. Discuss., 9(1), 1177-1208 (doi: 10.5194/tcd9-1177-2015)

Phillips T, Rajaram H, Colgan W, Steffen K and Abdalati W (2013) Evaluation of cryo-hydrologic warming as an explanation for increased ice velocities in the wet snow zone, Sermeq Avannarleq, West Greenland. J. Geophys. Res.: Earth Surf., 118(3), 1241-1256, ISSN 21699011 (doi: 10.1002/jgrf.20079)

Poinar K and 5 others (2015) Limits to future expansion of surfacemelt-enhanced ice flow into the interior of western Greenland. Geophys. Res. Lett., 42, 1800-1807, ISSN 00948276 (doi: 10.1002/2015GL063192.Received)

Poinar K, Joughin I, Lenaerts JTM and Van Den Broeke MR (2016) Englacial latent-heat transfer has limited influence on seaward ice flux in western Greenland. J. Glaciol., 1-16, ISSN 00221430 (doi: 10.1017/jog.2016.103)

Raymond C and Nolan M (2000) Drainage of a glacial lake through an ice spillway. Intl. Assoc. Hydrol. Sci. Publ., 264, 199-210, http://iahs.info/uploads/dms/iahs_264_0199.pdf
Schoof C (2010) Ice-sheet acceleration driven by melt supply variability. Nature, 468(7325), 803-806, ISSN 1476-4687 (doi: 10.1038/nature09618)

Selmes N, Murray T and James TD (2011) Fast draining lakes on the Greenland ice sheet. Geophys. Res. Lett., 38(15), ISSN 19448007 (doi: 10.1029/2011GL047872)

Selmes N, Murray T and James TD (2013) Characterizing supraglacial lake drainage and freezing on the Greenland Ice Sheet. Cryos. Discuss., 7(1), 475-505, ISSN 1994-0440 (doi: 10.5194/ tcd-7-475-2013)

Smith LC and 15 others (2015) Efficient meltwater drainage through supraglacial streams and rivers on the southwest Greenland ice sheet. Proc. Natl. Acad. Sci, 2000, 201413024, ISSN 00278424 (doi: 10.1073/pnas.1413024112)

Stevens La and 7 others (2015) Greenland supraglacial lake drainages triggered by hydrologically induced basal slip. Nature, 522(7554), 73-76, ISSN 0028-0836 (doi: 10.1038/nature14480)

Sundal A and 5 others (2009) Evolution of supra-glacial lakes across the Greenland Ice Sheet. Remote Sens. Environ., 113(10), 21642171, ISSN 00344257 (doi: 10.1016/j.rse.2009.05.018)

Sundal AV and 5 others (2011) Melt-induced speed-up of Greenland ice sheet offset by efficient subglacial drainage. Nature, 469 (7331), 521-524, ISSN 1476-4687 (doi: 10.1038/nature09740)

Tedesco $M$ and 5 others (2013) Ice dynamic response to two modes of surface lake drainage on the Greenland ice sheet. Environ. Res. Lett., 8(3), 034007, ISSN 1748-9326 (doi: 10.1088/1 748-9326/8/ 3/034007)

Tedstone AJ and 5 others (2015) Decadal slowdown of a land-terminating sector of the Greenland Ice Sheet despite warming. Nature, 526(7575), 692-695, ISSN 0028-0836 (doi: 10.1038/ nature15722)

Thomsen $\mathrm{HH}$ (1988) Mapping and modelling of glacier drainage in the paakitsoq basin, central west Greenland. Greenland Geol. Surv. Rep., 140, 114-117

Van De Wal RSW and 10 others (2015) Self-regulation of ice flow varies across the ablation area in south-west Greenland. Cryosphere, 9(2), 603-611, ISSN 19940424 (doi: 10.5194/tc-9603-2015)

van den Broeke M and 8 others (2009) Partitioning recent Greenland mass loss. Science (New York, N.Y.), 326(5955), 984-986, ISSN 1095-9203 (doi: 10.1126/science.1178176)

Van Der Veen CJ, Plummer JC and Stearns LA (2011) Controls on the recent speed-up of Jakobshavn Isbr??, West Greenland. J. Glaciol., 57(204), 770-782, ISSN 00221430 (doi: 10.3189/ $002214311797409776)$

Vaughan D (1993) Relating the occurrence of crevasses to surface strain rates. J. Glaciol., 39(132), 255-266

Yang K, Smith LC, Chu VW, Gleason CJ and Li M (2015) A caution on the use of surface digital elevation models to simulate supraglacial hydrology of the Greenland ice sheet. IEEE J. Selected Topics Appl. Earth Obs. Remote Sens., 8(11), 5212-5224, ISSN 21511535 (doi: 10.1109/ISTARS.2015.2483483)

Zwally HJ and 5 others (2002) Surface melt-induced acceleration of Greenland ice-sheet flow. Science (New York, N.Y.), 297(5579), 218-222, ISSN 1095-9203 (doi: 10.1126/science.1072708) 